\title{
Open and Distance Learning in French-Speaking Sub- Saharan Africa: A Literature Review
}

\author{
Emmanuel Béché \\ University of Maroua
}

\begin{abstract}
This article is a literature review on open distance learnings (ODL) in Francophone Sub-Saharan Africa (FSSA). The state of research on this question highlights many topics, such as the supporting reasons for the creation of ODL systems and their potentials. Success, difficulties, and issues linked to their implementation also hold a crucial place in this research. Besides, this literature review shows that studies on ODLs in FSSA emphasize the representations, motivations, and identities of students and university managers, including the historical and cooperative aspects of these third-generation learnings. While most of the research in this field are descriptive or exploratory, others are critical. Beyond these results, research must further explore many perspectives, mainly those related to teaching and learning practices, evaluation, social and university transformations, and the hybrid forms of learning.
\end{abstract}

Keywords: ODL, French-speaking Sub-Saharan Africa, literature review, research statement, African virtual university, francophone university agency 


\section{Introduction}

As Depover and Orivel (2012) and Loiret (2013a) point out in their studies, Open and Distance Learnings (ODL) have been developing since the latter half of the 1990s in French-speaking SubSaharan Africa (FSSA). Karsenti and Collin (2013) also note that States and universities in this part of Africa are interested in promoting these third-generation learning systems, despite their technical, socio-economic, and pedagogical deficits. If the early development of distance learnings in Africa involved only a few academic institutions such as the African Virtual University, Cheikh Anta Diop University of Dakar, the University Institute of Technology in Bandjoun, and the National Center for Tele-education of Madagascar; however, today close to hundred ODL systems exist. These training programs include local institutional initiatives as well as cooperative projects. The African Virtual University, the Agence Universitaire de la Francophonie and those conducted by Indian universities through the Pan African e-Network Project, are part of these international programs, thus increasing the number of ODL initiatives.

At the Agence Universitaire de la Francophonie alone, 25\% of ODL offered in 2015 around the world, are with African universities, which makes Africa its priority field regarding the development of these programs (Depover \& Orivel, 2012; Karsenti \& Collin, 2011). Although ODL projects in FSSA are in their early stages of development, Tonye (2013) shows that they are spreading considerably, mainly since they are now part of the priority educational plans of States and universities. In addition to this institutional dynamism, Obono Mba (2008) also invokes the high enthusiasm of African students for OLD. Besides Tonye (2013, p. 104) describes as "spectacular" their attraction to these learning modes. In 2014, for example, $77.25 \%$ of admissions to OLD programs managed by the Agence Universitaire de la Francophonie, emanated from Sub-Saharan Africa, of which $43.4 \%$ were from West Africa and $30.67 \%$ were from Central Africa. The two most represented French-Speaking countries were Cameroon (13.65\%) and Burkina Faso (10\%).

These are all contextual elements which make today, the ODL systems in FSSA constitute one of the topical topics of research in education (Depover \& Orivel, 2012). Even if 90\% of research currently done on ODL emphasized on those in the West (Ben Henda, 2011), those developing in this part of Africa also constitute more and more sources and avenues of inquiry (Loiret, 2013a). Books, articles, and thesis are thus written, both by local and foreign researchers, as described in the table below. 
Table 1

Panorama of Topics on ODL in FSSA

\begin{tabular}{|c|c|c|}
\hline $\begin{array}{l}\text { Justifying reasons for the implementation of the } \\
\qquad \text { OLD in FSSA } \\
\text { Baranshamaje (1996) } \\
\text { Guidon \& Wallet (2007) } \\
\text { Kane (2008) } \\
\text { Karsenti \& Collin (2010, 2011, 2013) } \\
\text { Lamago (2011) } \\
\text { Loiret \& Oillo (2013) } \\
\text { Loiret (2007) } \\
\text { Loiret (2008) } \\
\text { Ndiogou Ndiaye (2011) } \\
\text { Oillo \& Loiret (2006) } \\
\text { Tonye (2010) }\end{array}$ & $\begin{array}{l}\text { ODL as a solution to the problems of training in } \\
\qquad \text { FSSA universities } \\
\text { Baran shamaje (1996) } \\
\text { Coumaré (2010) } \\
\text { Guidon \& Wallet (2007) } \\
\text { Kane (2008) } \\
\text { Karsenti \& Collin (2010, 2011, 2013) } \\
\text { Lamago (2011) } \\
\text { Loiret \& Oillo (2013) } \\
\text { Loiret (2007, 2008) } \\
\text { Loiret (2013b) } \\
\text { Marquet, Mohib Najoua, Schaming \& Papi (2013) } \\
\text { Oillo \& Loiret (2006) } \\
\text { Tonye (2013) }\end{array}$ & $\begin{array}{l}\text { The ODL's potentials for FSSA universities } \\
\text { Baranshamaje (1996) } \\
\text { Depover \& Orivel (2012) } \\
\text { Dogbe-Semanou (2010) } \\
\text { Guidon \& Wallet (2007) } \\
\text { Karsenti \& Collin (2010, 2011, 2013) } \\
\text { Karsenti (2011) } \\
\text { Lamago (2011) } \\
\text { Lishou (2008) } \\
\text { Loiret (2006) } \\
\text { Ndiogou Ndiaye (2011) } \\
\text { Ndiogou Ndiaye (2011) }\end{array}$ \\
\hline \multirow{2}{*}{$\begin{array}{l}\text { The cooperative component of the OLD in FSSA } \\
\text { Ben Henda (2005) } \\
\text { Benchenna (2006, 2008) } \\
\text { Depover \& Orivel (2012) } \\
\text { Guévart \& al. (2009) } \\
\text { Guidon \& Wallet (2007) } \\
\text { Inzoli \& Zouya Mimbang (2013) } \\
\text { Kane (2008) } \\
\text { Loiret (2007, 2008, 2013a, 2013b) } \\
\text { Loiret \& Oillo (2013) } \\
\text { Marquet \& al. (2013) } \\
\text { Ndiogou Ndiaye (2011) } \\
\text { Oillo \& Loiret (2006) }\end{array}$} & \multirow{2}{*}{$\begin{array}{l}\text { Description of ODL implementa tion in FSSA } \\
\text { Akouete-Hounsinou Madoué (2012) } \\
\text { Candat (2002) } \\
\text { Diop (2005, 2015) } \\
\text { Dogbe-Semanou (2010) } \\
\text { Fournier Fall (2006) } \\
\text { Lekeaka Alemnge (2015) } \\
\text { Loiret (2008, 2013a, 2013b) } \\
\text { Ndiogou Ndiaye (2011) } \\
\text { Oillo et Loiret (2006) } \\
\text { Tonye (2013) } \\
\text { Touré (2014) }\end{array}$} & $\begin{array}{l}\quad \text { The historic dimension of ODL in FSSA } \\
\text { Guidon \& Wallet (2007) } \\
\text { Inzoli \& Zouya Mimbang (2013) } \\
\text { Kane (2008) } \\
\text { Kokou A wokou (2007) } \\
\text { Loiret \& Oillo (2013) } \\
\text { Loiret \& Oillo (2013) } \\
\text { Loiret (2007, 2013b) } \\
\text { Oillo \& Loiret, 2006 }\end{array}$ \\
\hline & & $\begin{array}{l}\text { Critical postures on ODL in FSSA } \\
\text { Benchenna }(2006,2008) \\
\text { Loiret }(2006,2007,2008)\end{array}$ \\
\hline $\begin{array}{l}\text { Motivations, Representations and Identities of } \\
\quad \text { Actors Relating to ODL } \\
\text { Depover \& Orivel (2012) } \\
\text { Obono Mba (2008) } \\
\text { Tonye (2010) } \\
\text { Karsenti \& Collin }(2010,2011,2013) \\
\text { Fournier Fall (2006) }\end{array}$ & $\begin{array}{l}\quad \text { Feasibility conditions for ODL in FSSA } \\
\text { Akouete-Hounsinou Madoué (2012) } \\
\text { Lamago (2011) } \\
\text { Obono Mba (2008) } \\
\text { Tonye (2008) }\end{array}$ & $\begin{array}{l}\text { Challenges of ODL in FSSA } \\
\text { Dogbe-Semanou (2010) } \\
\text { Guidon \& Wallet }(2007) \\
\text { Karsenti \& Collin }(2010,2011,2013) \\
\text { Tonye (2010) }\end{array}$ \\
\hline
\end{tabular}

Concerning these writings on ODL in FSSA, no work has so far established a literature review. The studies carried out by the Association for the Development of Education in Africa (2011), Depover and Orivel (2012), Guidon and Wallet (2007), Kane (2008), Karsenti and Collin (2011, 2013), Loiret (2013a), and Tonye (2008), examine just the state of development of ODL in Africa. None set the state of research on this topic. Although Peraya (2008) made a critical account of the book edited by Guidon and Wallet (2007) on comparative study on distance learning in Sub-Saharan Africa, he does not provide a more in-depth look at the state of this question in FSSA. In conclusion, this research status does not provide a clear understanding of the achievement and trends pointed out by researchers on ODL in FSSA. Hence this work, which presents a portrait of research on ODL in this part of Africa, would be useful for the structuring of this domain of knowledge. It thus highlights various topics developed on distance learning in FSSA, including those which justify the creation of this training mode in this context.

To constitute our corpus, we consulted more than 12 French open databases in social and human sciences, using research requests similar to "open and distance learning in French-speaking SubSaharan Africa." We thus systematically selected all the studies that deal with this topic. In this regard, we defined ODL as learning systems which can be synchronous or asynchronous, hybrid or not. In ODL, the rupture of the spatial unit between teachers and learners, the complementary and the plurality of learning situations, and the various forms of mediations are based, in whole or in part, on the use of computer networks (Choplin, 2002; Glikman, 2002; Dieumegard \& Durand, 2005). At the end of our data gathering, we collected 42 published papers on ODL systems in FSSA. The analysis of the lecture notes provides 10 highlighted points that characterized this research field, as described below. 


\section{Description of the ODLs Implemented in FSSA}

In the scientific literature on ODL in FSSA, the description of the implemented system occupies a special place. Condat (2002) describes thus the African Virtual University briefly five years after its launch. After reminding its ambitions, she exposes its techno-pedagogical system, which leads her to underline its old equipment and its high financial costs. She shows that the same observations as those put before to justify its implementation, resurface again. Loiret (2008) also concludes in the same way. While describing the 10 years of experience of this virtual university, he criticizes its technological positivist approach, before embarking on the characterization of the implementation methods of the distance learnings at the Agence Universitaire de la Francophonie (Loiret, 2013a, 2013b; Oillo \& Loiret, 2006). In the same way as these authors, Diakhaté (2014) and Diop (2015) expose both the successes and the tensions in distance education systems at the University of Cheikh Anta Diop of Dakar. AkoueteHounsinou Madoué (2012) reaches the same conclusion regarding distance learnings in Benin. In the same vein, Lekeaka Alemnge (2015), who examines the ODL system at the University of Buea (Cameroon), highlights two significant aspects: the steps and conditions for their implementation, and the components and methods of their operation. Ndiogou Ndiaye (2011) and Tonye (2013) both used this approach in their studies. The first drew a techno-pedagogical portrait of the ODL program at the University of Cheikh Anta Diop of Dakar. The second focused on the analysis of the distance master program in telecommunications at the National Advanced School of Engineering of Yaoundé. In this system, which he describes as a hybrid, he distinguishes three principal actors: pedagogical, administrative, and coordinators. For Dogbe-Semanou (2010) and Touré (2014) respectively, it is the limited interaction between these types of actors, which explains the high dropout rate amongst distance Togolese students, and the slight autonomy of those in West Africa in general.

Overall, descriptive research on ODL systems in FSSA brings out both successes and mistakes. To explain this latter aspect, Diop (2005) stress the insufficiencies in infrastructures facilities, distribution of tasks, and teachers' training and financial motivation. Akouete-Hounsinou Madoué (2012) also underlines their sociotechnical deficits and the low articulation conditions between distance and faceto-face mode. Ndiogou Ndiaye (2011) insists on the lack of distance learning development policies and the questionable institutional and social recognition of ODL graduates. For this author, as for Tonye (2013), it is the reasons why no matter the real projects conceived, there is a low rate of appropriation of the ODL by the local students, teachers, and university managers (Diop, 2015; Fournier Fall, 2006).

\section{Gaps in FSSA Universities: The Main Justifying Reasons for the Implementation of OLD}

The reasons underlying the interest and necessity of ODL projects for African universities are one of the most advanced topics. The most obvious ones highlight the shortcomings of these universities, hence the transversality of an African educational crisis idea in most research (Kane, 2008; Karsenti \& Collin, 2011; Loiret, 2008; Ndiogou Ndiaye, 2011). Baranshamaje (1996) and Oillo and Loiret (2006) also respectively emphasize these gaps as justifications for the implementation of ODL at the African Virtual University and the Agence Universitaire de la Francophonie. As written by Loiret and Oillo (2013), ODL projects at these two institutions consider educational systems in African universities as unsuitable for the evolution of knowledge and the needs of societies.

Moreover, they show that the teachers' qualifications represent the central area in which the educational crises in the ASSF are manifested (Oillo \& Loiret, 2006). These crises include the lack of qualified resources (Karsenti \& Collin, 2011, 2013), the limitations of their scientific, technical, and vocational 
training (Lamago, 2011) and the use of unskilled teachers (Guidon \& Wallet, 2007). Learning and research structures and infrastructures are also not spare. Baranshamaje (1996) and Ndiogou Ndiaye (2011) consider them to be absent, inadequate, or ineffective. The same applies to academic staff, and technological and educational systems, which Lamago (2011) describes as defective. This situation leads to further gaps and deficiencies of African university systems, namely the overcrowding of halls, the inadequacy between employment and learning, and the worrying issue of unemployment (Karsenti \& Collin, 2010; Ndiogou Ndiaye, 2011).

Justifying the ODL provided by the Agence Universitaire de la Francophonie for French-speaking African universities, Oillo and Loiret (2006) also emphasize on their limited access to scientific and technical information. For them, the libraries and documentary resources centers of African universities are poorly equipped and not updated. In Lamago's (2011) point of view, this leads to a low pedagogical involvement of teachers and researchers in the production of knowledge. For its side, Baranshamaje (1996) places the reason for this low pedagogical productivity in the anachronistic, impertinent, and unsuited character of the educational programs of African universities. For him, as for Ndiogou Ndiaye (2011), this result in deterioration of the quality of teaching and research, as well as the imbalance between learning and employment, and a high percentage of failure, dropout, and repetition (Lamago, 2011). In addition to this documentary and curricular slump, Ndiogou Ndiaye (2011) also points out the role of financial difficulties, financing crises, and education planning deficits in the deterioration of the Sub-Saharan African education system. Tonye (2010) adds four other factors that are more global and structural, such as the obligations linked to the development of the socio-professional world, the competitiveness of Western universities, the globalization of education, and the obsolescence of African academic governance.

Karsenti and Collin (2010, 2011, 2013) summarize these shortcomings of the French-speaking SubSaharan African universities in three-fold obligations: strong staff growth, reduced finances, and unprofitable job market. It is in this sense that Baranshamaje (1996) brings into question all of the components and missions of these University systems. He then concludes that they have failed in the past and, moreover, are not prepared to meet the challenges of the future. Hence the use of ODL systems as solutions to overcome their imperfections (Karsenti \& Collin, 2010, 2011, 2013; Oillo \& Loiret, 2006; Tonye, 2010).

\section{ODL: A Solution to the Problems of Training in Universities of FSSA}

As it appears in these two articles (Baranshamaje, 1996; Loiret, 2008), research on ODL in FSSA does not only emphasize the weaknesses of African university systems; it also presents distance learning as the solution. So, ODL systems as the answer to the educational crisis in Africa is one of the most advanced topics in this area. For Kane (2008), this perspective links the international distance learning offer to the problems diagnoses on which it is building as an ideology. Guidon and Wallet (2007) as well as Coumaré (2010) present thus the ODL as engaging answers to gaps in initial and continuous training within the French-speaking Sub-Saharan universities. Lamago (2011) also describes these thirdgeneration learning modes as an alternative remedy to the difficulties the African higher education face. For Kane (2008), ODL projects function as antidotes to the challenges of African universities. Karsenti and Collin (2010, 2011) characterize them as the "appropriate answer" (p. 74) or the "interesting alternative" (p. 494) suited to African academic crises. These two last authors also explain that as a necessity both for students and teachers, ODL systems in Africa allow the intervention of experts from the developed countries. As written by Oillo and Loiret (2006), the implementation of distance learning 
programs in Sub-Saharan is expected to solve its higher education crisis, which has had no outcome despite many summits and conferences on education in Africa. In brief, authors describe them as the solution to four main problems: insufficient professional training, university massification, limited access to library and ICT resources, and poor quality of education and research.

This conceptualization of ODL in FSSA appears mostly in studies on their implementation in this context. So, talking about the African Virtual University, Loiret (2008) says that its creation was the World Bank's answer to crises African higher education. Likewise, while describing the ODL at the Agence Universitaire de la Francophonie, Marquet, Mohib Najoua, Schaming, and Papi (2013) consider them as a response to the urgent need of empowering Africa in solving its academic crisis. It is also in that perspective that Loiret and Oillo (2013) conceive French-speaking ODL. For them, the creation of digital Francophone campuses in African universities fights against the quantitative and qualitative deficiency of their scientific and academic documentation. Globally, the description of the implementation of ODL in FSSA in the scientific literature makes them an opportunity to solve the weakness of its university systems.

The advertisement made by Loiret (2013b) on continuous and distance learning in computerized information network at the Ecole de Bibliothécaires Archivistes et Documentalistes de Dakar is a pertinent example. He describes it as the best alternative and the way to a new rise of this school. ODL programs thus intervene here at a critical moment whereby the institution was going through some crises: the loss of its regional vocation, the decrease in the number of international students and the inadequacy between learning curriculums and the societal development. Tonye (2013) also places the creation of the ODL in Master of Telecommunication at the National Advanced School of Engineering of Yaoundé, as the response to the need for engineers in that domain.

\section{The Potentials of ODL for FSSA Universities}

By describing the ODL projects as answers to FSSA university crises, research indeed mentions their qualities for these institutions. Authors like Baranshamaje (1996) and Karsenti and Collin (2010) emphasize the benefits of ODL, placing them on a scale that does not evaluate their limits. In this regard, Ndiogou Ndiaye (2011) describe distance learning programs as a "real hope" for FSSA universities (p. 129), and Lamago (2011) sees in them a "beneficial alternative for professional's continuing education" (p. 13). Dogbe-Semanou, 2010) also stresses the contributions of ODL to the solving of African educational crises, as a battery of solutions. Besides, Baranshamaje (1996) justifies the implementation of ODL systems at the African virtual university. He argues that they are the "the only way" for Africa to achieve education for all (p. 123). He explains that the technology of distance education programs possess enormous potentiality by which it can improve the quality education in Africa.

Comparing the ODL projects in FSSA, Guidon and Wallet (2007) also highlight their profitability for this continent and conclude that without them, "it would take 200 years to train the needed number of teachers" (p. 16). Besides, Lamago (2011) mentions that the implementation of ODL projects in FSSA would then make it possible to curb the significant deficiency of professionals and to reinforce their contributions to the development of their countries (Lamago, 2011). These are as many as qualities of the ODL for the African countries that Depover and Orivel (2012) set out also to demonstrate.

Also, based on a specific case, Lishou (2008) exposes, as the coordinator of the ODL system at the Université Cheikh Anta Diop of Dakar, its benefits. Among these lasts, he highlights the significant improvement in the quality of teaching and the qualitative transformation of the educational format 
coupled with a substantial return. On the student's side, the author testifies that distance learning allows a high quality/comfort relationship of course follow-up, which was not the case with overcrowded and non-equipped classes. Analyzing the contexts and practices of ODL projects in Sub-Saharan Africa, Karsenti and Collin (2010, 2011, 2013) also present their advantages for this continent. They explain that these potentials are closely related to the objective of qualifying vocational training of workers, which Africa needs for its development (Karsenti \& Collin, 2013). In the same way as Depover and Orivel (2012) or Ndiogou Ndiaye (2011), these authors show that, in this context, OLD systems allow accommodating a more significant and diverse number of students than in the traditional classes. So, for them, this learning mode can help to efficiently develop skilled African laborers (Karsenti \& Collin, 2011). They support that, through distance learning, FSSA will no longer need external expertise for its development. On the contrary, ODL programs allow it to keep its human capital locally.

One of the ODL potentials on which Karsenti and Collin (2010) emphasize for this part of Africa concern precisely the professional development of Africans through continuing education and a long life learning. They argue that ODL enables learners to follow vocational training out of their immediate socio-professional environment while remaining on the spot. By this way, distance learning programs give Africa the means to stop the brain drain and to have qualified professionals available and on-site (Karsenti \& Collin, 2011). Besides, by studying the profiles of ODL students at the Agence Universitaire de la Francophonie, these authors highlight favorable results obtained. Even if they find some differences in students' achievement, they do not attribute them to the ODL. For them, these dissimilarities occur in any continuing education (Karsenti \& Collin, 2010). They explain thus that distance learning systems can provide an enormous potential for the professional development of Africans while being on the spot.

\section{The Cooperative Component of the OLD in FSSA}

Research on OLD systems in FSSA shows that they are part of partnership networks. If authors like Benchenna (2006, 2008) criticize them, thinking that they are not advantageous to African education, others as Ben Henda (2005) and Guévart et al. (2009) emphasize their importance for African universities.

Kane (2008) and Ndiogou Ndiaye (2011) distinguish three types of partnership actors involved in the implementation of ODL projects in FSSA. The first category includes international organizations such as the Association pour le Développement de l'Education en Afrique, the Agence Universitaire de la Francophonie, the World Bank, the United Nations for Education, Science and Culture Organization, and the United Nations Development Program. The second group refers to countries such as Belgium, Canada, the United States, France, India, and Switzerland. The third is made up of networks, initiated by any of the countries or organizations above, and constitute the frameworks for the development of ODL systems in Sub-Saharan Africa. In this last category of ODL projects in Africa, Depover and Orivel (2012) include the Regional Bureau for Education in Africa, the French-speaking university campuses, and the center for applications, studies, and resources in distance learning. Loiret (2013a) also mentions the Institue for Information and Communication New Technologies, the Pan-African network project, the African Distance Education Network, the African Virtual University, the French-speaking Virtual University, and the Swiss Virtual University. As Depover and Orivel (2012) and Guévart et al. (2009) write, these interventions of foreign partners reflect the high involvement of the West in the development of ODL systems in FSSA, and thus constitutes one of their specificities. Besides, Guidon and Wallet (2007) conclude that these ODL are the result of a series of recommendations stemming 
from various meetings and international cooperation on education and the information society in Africa. Ndiogou Ndiaye (2011) also underlines the role the global partnerships in the conception and implementation of distance training programs in FSSA.

Among the foreign partners of the ODL projects in FSSA, the Agence Universitaire de la Francophonie and its French-speaking digital campuses are the most described (Loiret, 2013a, 2013b), which appears as the colonial heritage of this part of Africa (Inzoli \& Zouya Mimbang, 2013). Most researchers like Benchenna (2008), Diop (2015), Fournier Fall (2006), Kane (2008), Marquet et al. (2013), and Oillo and Loiret (2006) fully underline their role and action in the implementation of distance learning projects in FSSA. According to Loiret $(2007,2008)$, it is the Agence Universitaire de la Francophonie which validates their creation and facilitates their development through its digital campuses. Marquet et al. (2013) define these virtual campuses as mechanisms put in place by this Francophone Agency in African public universities, intended to follow them in their educational technology integration (Loiret, 2007). Ben Henda (2005) also argues that these partnerships are beneficial for Africa for two main reasons. The first is that they contribute to ensuring the quality of higher education in the South and to reducing the digital breaking between this part of the globe and the North. The second reason is that they are as an opportunity for the Southern countries to contribute to the standardization of the ODL systems by valuing their linguistic and cultural specificities. Especially for Loiret and Oillo (2013), most of these partnerships take into account learning programs and diplomas existing within the local African universities.

If some authors like Benchenna (2008), Loiret (2013a), and Marquet et al. (2013) exalt these global partnerships, others criticize them. Benchenna $(2006,2008)$ presents thus French cooperation in ODL projects in Africa, not as an act of solidarity, but as a strategy of its geopolitical position. For this researcher, the Agence Universitaire de la Francophonie is more useful for the internationalization of French university courses than for African universities, especially regarding the globalization of education and the competition with the Anglo-Saxon ODL offerings. He also questions their economic logic and their deterministic and paternalistic approaches, which increase the dependence of the universities of the South on those from the North. Benchenna (2008) also explains that these partnerships within the implementation of ODL systems in Africa draw a division of roles in which experts from Northern countries are designers and those from the South as the subcontractors.

\section{The Historical Dimension of ODL in FSSA}

The historical description of ODL systems in FSSA is one of the least advanced topics in the scientific literature. Nevertheless, research carried out by Kane (2008), Loiret (2006, 2007, 2008) and Loiret and Oillo (2013) outline their transformation. Each of these authors describes the evolution of the distance learning program at the Agence Universitaire de la Francophonie. Kokou Awokou (2007) also distinguishes two significant movements in the development of the ODL programs in some Frenchspeaking countries in West Africa. The first step is that of the use of audiovisual media. He situates this early stage before 1990. Distance and mediation tools were postal, print, audio, and videos cassettes. Distance education courses were thus in the form of correspondence courses and educational radio. He shows that this program was designed to improve literacy and school enrolment of students in rural areas. On the contrary, the second moment of ODL is digital. Here, distance is expressed in of the internet technologies and intervenes in a context of educational crisis and economic gloom. If the author points out a breaking between the two moments due to the cessation of the first experiments, he shows that there is a close relationship between the evolution of the ODL program and its political, 
economic, technological, and educational context. He also mentions the role of external partners and international meetings in the development of ODL systems in French-speaking West Africa.

Concerning the ODL systems in FSSA, Guidon and Wallet (2007) indicate that they started in 1970 as correspondence courses for teachers. However, they mainly result from the World Conference on Higher Education in Paris in 1998. Besides, these authors wrote that distance education programs are also part of recommendations of the World Education seminar held in Dakar in 2000 and the Committee on the Teachers' Status organized in Geneva the same year. Inzoli and Zouya Mimbang (2013) describe ODL systems in FFSA as "ready-made" training, contrary to those implemented in English-speaking Africa where they are similar to industrial enterprises. For these researchers, the history of ODL programs in African countries agrees with the paths of their colonial history. In FSSA mainly, they remain touched by the intervention of the Agence Universitaire de la Francophonie of which Loiret $(2007,2013 \mathrm{~b})$ makes the historical description. He shows that the ODL programs offered by this francophone agency began in 1980 . Their objectives were to solve the limited access to academic and scientific libraries in French-speaking African universities, by putting in place an open resources program (Oillo \& Loiret, 2006). Ten years later, this program has been extended by including the development of ODL systems, particularly in French-speaking Africa. It is particularly in this regard that Loiret and Oillo (2013) situate the creation of the French-speaking virtual university in 1998 and its digital campuses in 2000.

\section{Motivations, Representations, and Profiles of ODL Users}

The scientific research on the ODL systems in FSSA also emphasizes the motivations and representations of students and managers towards them. Two aspects of these social images appear in the literature: the institutional one and those from the learners. Describing the representations of African institutional managers on ODL, Depover and Orivel (2012) show that they have a positive attitude to integrate this program into their educational system. Moreover, Obono Mba (2008) argues that there is a consensual opinion on this point amount university managers. She points out that in Gabon, university leaders perceive the ODL programs as a strategy to help students developing more skills and knowledge. She also explains teachers consider distance education as a tool to fulfill the needs of continuous education. That is why institutional managers exalt and sublimate ODL systems and technology. On the students' side, Tonye (2010) shows that the attraction for ODL programs is also mesmerizing, even though they have no idea at the beginning of their learning. In fact, at the first steps of their distance learning, Karsenti and Collin (2011) note that they proceed on a process of familiarization with the systems. Students thus provide psychologic and methodological efforts to adjust their initial conception of the ODL systems to the requirement of this later. As they use it progressively, their representations change as to innovate both in collaborative and individualized activities (Karsenti \& Collin, 2011).

Regarding the motivations for the ODL programs, Karsenti and Collin (2011) show that for these students, the development of their professional skills is the primary factor. Students find in distance education programs a way to improve and remedy their gaps connected with their education, employability, and adaptation to the socio-economic and professional issues (Karsenti \& Collin, 2010). For Karsenti and Collin (2013), it is the reason why students enrolled in the ODL programs in FSSA are in majority practitioners, who have a job. Fournier Fall (2006) defines them as a public different from students of traditional higher education. These distance learning students are adults, workers, and graduates of higher education, who have acquired initial training and some professional experience 
(Karsenti \& Collin, 2011). They are also mostly city dwellers; they are people that can bear the high costs of registration in an ODL system and to acquire documentary and technological facilities necessary for distance learning (Fournier Fall, 2006).

\section{Feasibility Conditions for ODL in FSSA}

Research on the ODL systems in FSSA also evaluate their implementation factors. In this regard, the study carried out by Tony (2008) underlines their low-deployment in Central Africa and explains their feasibility conditions. He concludes that improving distance learning systems in this African sub-region goes through their contextualization, which is essential to meet local issues. While emphasizing the importance of developing technological and structural infrastructures, Tonye (2008) also presents the social anchoring of technologies as an essential condition for their implementation. He shows that for the ODL systems to develop, they must adapt to the African context through an engineering model of learning, which enlightens their practical implementation possibilities.

Akouete-Hounsinou Madoué (2012) also explains that this adaptation of ODL systems to local African contexts must go through a modelization, which can identify and analyze local needs first and foremost. She argues that the ODL programs in Sub-Saharan Africa must be a contextualized answer to meet the local concern, rather than a method which obliges to adopt those whose contents and objectives are far from African realities. Therefore, she insists on the optimization of their administrative, pedagogical, and technological methods in the African contexts, while overcoming the difficulties associated with traditional continuing education. Lamago (2011) also stresses these aspects. By observing closer the interest and feasibility of distance learnings for Cameroonian teachers, he emphasizes, on the one hand, their technological, structural, financial, administrative, and pedagogical predispositions, and on the other side, the availability and usability of educational technology resources. Finally, Obono Mba (2008) summarizes the conditions of a successful distance learning project in Sub-Saharan Africa in four requirements: promotion of techno-pedagogical skills, psychological preparation, financial and technological supports, and development of institutional partnerships.

\section{Challenges of ODL in FSSA}

Taking into consideration the mixed picture of the ODL programs in FSSA, many researchers expose the challenges to be met. The most important one is about the information technology equipment.. In this regard, Karsenti and Collin (2010, 2011) show that it is essential that institutions and individuals should equip themselves with the necessary tools for the success of ODL projects. They suggest then to reduce the technical distance, which also includes the technical mastery of an ODL systems.

Apart from this challenge, Karsenti and Collin (2010, 2011) also underline the one related to the development of students' skills. They argue that the development of such learning modes in SubSaharan Africa depends on students' ability to self-discipline, autonomy, responsibility, and selfregulation. Hence, the importance of reducing the temporal distance. For Guidon and Wallet (2007), this is the way to attenuate the high dropout rates in distance learning programs in Africa, as well as to minimize sociocultural distance. Describing this last challenge regarding the evolution of students' representations toward the ODLs, Dogbe-Semanou (2010) shows that personal factors as motivation and positive attitude towards technologies and distance are essential to promote. Tonye (2010) reaches the same conclusion regarding teachers' training and skills. Dogbe-Semanou (2010) explains that teachers' skills, as well as students' digital literacy and institutional policies, contribute to improving 
the retention and persistence rates of learners in ODL programs, which is another challenge in the French-speaking African context.

\section{Critical Postures on ODL in FSSA}

If many researchers on ODL in FSSA carried out their studies in a descriptive or exploratory approach, some like Loiret $(2006,2007,2008)$ and Benchenna $(2006,2008)$ adopt critical postures nevertheless. The first examines the ODLs at the African Virtual University, while the second author analyses those at the Agence Universitaire de la Francophonie.

Studying the first decade of the African Virtual University, Loiret $(2006,2007,2008)$ examines three crucial aspects: the reasons justifying its creation, the approach of its design and implementation, and its governance and development policy. Thus, Loiret (2007) shows that its foundation dwells on motives and objectives that systematically challenge African university systems. For this author, these reasons which are the source of their delay and their inability to fill the gaps, do not determine their causes. He explains that these arguments do not take into consideration the context of structural adjustment policies in which African universities have evolved. Hence, for Loiret $(2006,2007)$, the creation of the African Virtual University involves a mistake in the conception and appreciation of the African academic contexts, as well as an attempt to instrumentalize innovation. Reinforced by a deterministic technological approach, which gives priority to technical and economic materials over local realities and resources, this innovation perspective was leading to bring the ODL systems out of African context. Because of the challenges of African universities, Loiret $(2007,2008)$ shows that the World Bank presented the African Virtual University as the only solution, endowed with techno-pedagogical qualities by which it would transform them. Besides, this author considers the inadaptability of the ODLs at the African Virtual University to the African context, as one of the causes of the end of his limitless ambitions. Except that the critics he addresses, benefit the strategic aspirations of the Agence Universitaire de la Francophonie to which he belongs.

Benchenna (2006, 2008) also shows that like the African Virtual University, the distance learning systems at the Agence Universitaire de la Francophonie function as a solution to African universities crisis. He even sees in these ODLs a paternalistic approach and a technological determinism that relegate the interest given to local resources and issues. For him, the implementation of distance learnings at the Agence Universitaire de la Francophonie is a competitive response to the African Virtual University and the English-speaking world initiatives which dominate the global learning market (Benchenna, 2008). He also presents francophone ODL systems as the right arm of the internationalization of French training policy in a context of global education. This author demonstrates that ODL systems at the Agence Universitaire de la Francophonie are not only educational, they are also a mechanism which causes the dependence of French-speaking African universities towards their counterpart in the North. Besides that, Benchenna (2006, 2008) supports that distance learning at this francophone agency reduces the international movement of African students, minimize their accessibility to education, and redistribute the roles between Northern and Southern actors.

\section{Conclusion}

Throughout this work, we have described the state of research on ODLs in FSSA, which brings out its portrait throughout the identification of some main topics. One of them refers to the reasons justifying 
the implementation of distance learning systems in this part of Africa. The scientific literature on this issue leans on the deficiencies of its university system: insufficiently qualified teachers, lack of structures and infrastructures, university massification, poor library, and funding crisis, which weakens learning and research. Therefore, authors like Baranshamaje (1996) describe ODL systems as a solution to these educational crises, which engender the inability of African universities to adapt themselves to the world and to participate in the development of their countries. Research on distance learning systems in FSSA shows that their openness and flexibility make them able to reach a significant number of students and to facilitate their socio-professional development through expertise from Northern countries (Karsenti \& Collin, 2011). While some researchers appreciate the partnerships with the North, which constitute one of the characteristics of ODL in FSSA (Guévart et al., 2009), others like Benchenna (2008) see them as a geopolitical positioning strategy of Western countries. Despite these ODL systems are an outcome of international meetings (Kane, 2008), Inzoli and Zouya Mimbang (2013) describe them as resulting from the colonial history of African nations, hence the importance of the Agence Universitaire de la Francophonie in FSSA (Loiret, 2013a).

The scientific literature on the ODL projects in this part of Africa highlights promising discourses of institutional managers. Researchers also underline the positive and evolving representations of students in ODL systems in FSSA. These students register in distance learning programs given their professional development (Karsenti \& Collin, 2010). In this regard, many authors stress the description of the implementation and development conditions of ODL projects in this context. Like Tonye (2008), they thus expose their successes as well as their hesitation due to several lacks. As solutions to improve ODL projects, these authors list various challenges, like technological equipment, promotion of local skills, ODL development policies, funding policies, and their contextualization (Guidon \& Wallet, 2007). It is related to this latter aspect that Benchenna (2008) and Loiret (2008) address criticisms respectively to the ODL at the Africa, Virtual University, and the Agence Universitaire de la Francophonie.

Regarding the dynamic of ODL projects in FSSA, this literature review shows that research must particularly emphasize many issues. One of them concerns their history, including their socio-cultural implementation. The innovations they bring and the transformations they generate in the organization of African universities should also be analyzed. Their hybridization, and precisely the articulation between the distance mode and the traditional learning, are another perspectives. In the same way, it is essential to examine the socio-pedagogical practices in ODL programs and to analyze how participants appropriate this third-generation education. 


\section{References}

Akouete-Hounsinou Madoué, F. (2012). La formation continue à distance des enseignants du secondaire au Bénin : Réalités et perspectives [Continuous Distance Education of Secondary School Teachers in Benin: Realities and Prospects] (Doctoral dissertation). Retrived from https://papyrus.bib.umontreal.ca/xmlui/handle/1866/9003

Association for the Development of Education in Africa. (2011). Open and distance learning in subSaharan Africa. An overview of Francophone countries. Abidjan: Association for the Development of Education in Africa.

Awokou, K. (2007). De l'utilisation des médias et des technologies de l'information et de la communication dans l'éducation de 196o à 2006. Le cas du Togo. [The use of the media and information and communication technologies in education from 1960 to 2006. The case of Togo]. (Doctoral dissertation). Retrieved from https://tel.archives-ouvertes.fr/tel-00139109

Baranshamaje, E. (1996). The African virtual university (AVU): Feasibility and preparation of prototype service phase. Washington: World Bank.

Benchenna, A. (2006). Réduire la fracture numérique Nord-Sud : Une croyance récurrente des organisations internationales? [Bridging the North-South digital divide: A Recurring belief of international organizations?]. Terminal, 95-96, 33-46.

Benchenna, A. (2008). Universités à l'ère numérique. Vers de nouveaux rapports entre pays du nord et pays du sud ? [Universities in the digital age. Towards new relations between Northern and Southern countries ?]. Distances et Savoirs, 6(1), 99-116. doi:10.3166/ds.6.99-116

Ben Henda, M. (2005, March). E-learning et normalisation : Des opportunités de contribution pour les pays émergents [E-Learning and Standardization: Contribution Opportunities for Emerging Countries]. Paper presented at the International Conference of the International Association of French Language. La langue française dans l'aventure numérique. Paris. Retrieved from: https://halshs.archives-ouvertes.fr/sic o0134624/document

Ben Henda, M. (2011). La temporalité "hyper cycle" des standards e-learning dans le contexte des pays émergents [The "hyper cycle" temporality of e-learning standards in the context of emerging countries]. In M. Ben Henda, \& E. Tonye (Eds.), TIC et éducation en Afrique : Applications, recherches et perspectives [ICT and Education in Africa: Applications, Research and Prospects] (pp. 129-183). Paris: L’Harmattan.

Choplin, H. (2002). Innover avec les formations ouvertes ? Entre innovation et formation ouverte, les nouveaux dispositifs de formation [Innovate with open education? Between innovation and open training. The new training systems]. Éducation Permanente, 23. Retrieved from https://edutice.archives-ouvertes.fr/edutice-00000620/document

Condat, S. (2002). L'université virtuelle africaine [The African Virtual University]. Revue Internationale d'Éducation de Sèvres, 31, 14-15. doi: 10.4000/ries.1806

Coumaré, M. (2010). La formation à distance (FAD) et les technologies de l'information et de la communication pour l'éducation (TICE) au service de la professionnalisation des 
enseignants au Mali : Une approche évaluative de dispositifs expérimentaux [Distance learning and information and communication technologies for education for teacher professionalization in Mali: An Evaluative approach of experimental systems] (Doctoral dissertation). Retrieved from https://tel.archives-ouvertes.fr/tel-00545798

Depover, C., \& Orivel, C. (2012). Les pays en développement à l'ère de l'e-learning [Developing countries in the era of e-learning]. Paris : IIPE.

Diakhaté, D. (2014). Introduction pionnière du e-learning à l'université et son rôle dans l'élaboration de nouvelles compétences technologiques: Le cas de l'EBAD [Pioneering introduction to elearning at the university and its role in developing new technological skills: The case of school of librarians, archivists and documentalists of Dakar]. Knowledge Management for Development Journal, 1O(2), 19-32. Retrieved from https://halshs.archives-ouvertes.fr/hal$\underline{01077000}$

Dieumegard, G., \& Durand, M. (2005). L'expérience des apprenants en e-formation : Revue de littérature [The experience of learners in e-learning: Literature Review]. Savoirs, 1(7), 93-109. doi:10.3917/savo.007.0093

Diop, M. L. (2015). E-Learning dans l'enseignement supérieur au Sénégal : Entre succès et tensions : Cas de deux établissements de l'université de Dakar [E-Learning in higher education in Senegal: Between success and tensions: The case of two institutions of the University of Dakar]. Retrieved from http://www.adjectif.net/spip/spip.php?article352

Dogbe-Semanou, D. A. K. (2010). Persévérance et abandon des apprenants à distance en Afrique subsaharienne francophone. Quelques pistes de recherche [Perseverance and abandonment of distance learners in French-speaking Sub-Saharan Africa. Some lines of research]. Frantice.net, 1O, 42-55. Retrived from http://www.frantice.net/index.php?id=136

Fournier Fall, A. (2006). Enseignement à distance supporté par les NTIC au Sénégal : Vers l'accession d'un public nouveau à l'enseignement supérieur ? Étude empirique sur le profil des étudiants de l'enseignement à distance supporté par les NTIC au Sénégal [Distance learning supported by ICTs in Senegal: Towards the access of a new public to higher education? Empirical study on the profile of distance education students supported by ICTs in Senegal]. (Doctoral Dissertation). Retrieved from https://doc.rero.ch/record/8003/files/FournierA.pdf

Glikman, V. (2002). Apprenants et tuteurs : Une approche européenne des médiations humaines [Learners and Tutors: A European Approach to Human Mediations]. Éducation Permanente, 152, 55-69. Retrieved from https://www.cairn.info/revue-hermes-la-revue-2006-2-page117.htm

Guévart, E., Billot, D., Paraïso, N. M., Guillemin, F., \& Briançon, D. (2009). E-Learning and NorthSouth collaboration: The experience of two public health schools in France and Benin. Pan African Medical Journal, 3(5). Retrieved from http://www.panafrican-medjournal.com/content/article/3/5/full 
Guidon, J., \& Wallet, J. (dir.). (2007). Formation à distance en Afrique subsaharienne : Études comparées [Distance Education in Sub-Saharan Africa: Comparative Studies]. Paris : UNESCO/BREDA. Retrieved from http://unesdoc.unesco.org/images/0015/001567/156795f.pdf

Inzoli, A., \& Zouya Mimbang, L. (2013, September). The intercultural perspective of e-learning programs and the use of new technologies in Africa. Paper presented at the Third Congress of the University Network for Development Cooperation. Imagining cultures of cooperation: Universities networking to face the new development challenges. University of Turin, Italy.

Kane, O. (2008). La FAD en Afrique francophone : Éléments historiques et enjeux récents [The Distance education in Francophone Africa: Historical elements and recent issues]. Distances and Knowledges, 6, 69-82. doi:10.3166/ds.6.69-82

Karsenti, T., \& Collin, S. (2010). Les formations ouvertes à distance (FOAD) : Quelle contribution au développement de professionnels qualifiés en Afrique ? [Open and distance learning (ODL): What contribution to the development of qualified professionals in Africa?] Questions Vives, 7(14). Retrieved from http://questionsvives.revues.org/536

Karsenti, T., \& Collin, S. (2011). Les formations ouvertes à distance, leur dynamique et leur contribution en contexte africain [Open and distance learning, their dynamics and their contribution in African context]. Distances et Savoirs, 9, 493-514. doi:10.3166/ds.6.69-82

Karsenti, T., \& Collin, S. (2013). Using IT for distance learning: Benefits and challenges for African learners. Formation et Profession, 2O(2), 13-25. doi:10.18162/fp.2012.178

Lamago, M. F. (2011). ). La formation continue à distance des enseignants au Cameroun : Enjeux et nouveaux défis pour l'école normale supérieure [Continuing distance education for teachers in Cameroon: Issues and new challenges for higher teacher training college] [Electronic document]. Retrieved from http://isdm.univtln.fr/PDF/isdm39/Article Isdm Ticemedo9 Lamago\%20ok.pdf

Lekeaka Alemnge, F. (2015). Distance Education at the University of Buea, Cameroon. Journal of Educational Policy and Entrepreneurial Research, 2(1), 34-42. Retrieved from http://www.iiste.org/Journals/index.php/JEPER/article/view/19020

Lishou, C. (2008). La web-TV éducative : Alternative aux formations de masse dans les universités africaines [The Educational Web-TV: Alternative to Mass Training in African Universities]. Distances et Savoirs, 6(4), 619-628. Retrieved from https://www.cairn.info/revue-distanceset-savoirs-2008-4-page-619.htm

Loiret, P.-J. (2006). L'université virtuelle africaine : Ambitions sans limite, limites d'une ambition [The African virtual university: Ambitions without limits; the limits of an ambition]. Hermès, 45, 123-128. Retrieved from https://www.cairn.info/revue-hermes-la-revue-2006-2-page$\underline{123 . h t m}$

Loiret, P.-J. (2007, November). L'enseignement à distance et le supérieur en Afrique de l'Ouest. Une université façonnée de l'extérieur ou renouvelée de l'intérieur ? [Distance education and 
higher education in West Africa. An university shaped from the outside or renewed from the inside?] (Doctoral dissertation). Retrieved from https://tel.archives-ouvertes.fr/tel-00192921

Loiret, P.-J. (2008). L'université virtuelle africaine : L'enseignement à distance en trompe-l'œil ? [The African virtual university: Distance learning in trompe-l'oeil?] Distances et Savoirs, 2(6), 187209. doi:10.3166/ds.6.187-209

Loiret, P.-J. (dir.). (2013a). Un détour par le futur. Les formations ouvertes et à distance à l'Agence Universitaire de la Francophonie 1992-2012. [A detour through the future. Open and distance learning at the Agence Universitaire de la Francophonie 1992-2012]. Paris: Archives Contemporaines. Retrieved from http://www.bibliotheque.auf.org/doc num.php?explnum id=822

Loiret, P.-J. (2013b). La formation ouverte et à distance à l'École des bibliothécaires, archivistes et documentalistes (EBAD) de Dakar : Une "bonne pratique" reproductible ? [Open and distance learning at the School of librarians, archivists and documentalists of Dakar: A reproducible "good practice"?] In P.-J. Loiret (Ed.), A detour through the future. Open and distance learning at the Agence Universitaire de la Francophonie 1992-2012 [A detour through the future. Open and distance learning at the Agence Universitaire de la Francophonie 1992-2012] (pp. 125-137). Paris: Archives Contemporaines.

Loiret, P.-J., \& Oillo, D. (2013). Histoire d'un dispositif de formation ouverte et à distance francophone [History of a Francophone open and distance training system]. In P.-J. Loiret (Ed.), A detour through the future. Open and distance learning at the Agence Universitaire de la Francophonie 1992-2012 [A detour through the future. Open and distance learning at the Agence Universitaire de la Francophonie 1992-2012] (pp. 7-20). Paris: Archives Contemporaines.

Marquet, P., Mohib Najoua Schaming, C., \& Papi, C. (2013). Les campus numériques francophones (CNF) de l'Agence Universitaire de la Francophonie (AUF) en Afrique : Entre politique d'intégration et modèle d'appropriation des TICE [The Francophone digital campuses of the agence universitaire de la Francophonie (AUF) in Africa: Between Integration Policy and ICT Appropriation Model]. In P.-J. Loiret (Ed.). A detour through the future. Open and distance learning at the Agence Universitaire de la Francophonie [A detour through the future. Open and distance learning at the Agence Universitaire de la Francophonie 1992-2012] 1992-2012 (pp. 21-30). Paris: Archives Contemporaines.

Ndiogou Ndiaye. (2011, June). Les Technologies de l'information et de la communication et l'enseignement à distance dans un environnement de massification des effectifs d'étudiants : Le cas de l'Université Cheikh Anta Diop de Dakar (UCAD) [Information and communication technologies and distance learning in a massive student enrollment environment: The case of the Cheikh Anta Diop University of Dakar]. (Doctoral dissertation). Retrieved from https://www.theses.fr/2011BOR21812.pdf

Obono Mba, A. (2008, mai). La formation à distance au Gabon. Enjeux et perspectives [Distance education in Gabon. Issues and perspectives]. (Doctoral Dissertation). Retrieved from http://www.theses.fr/2008ROUEL602 
Oillo, D., \& Loiret, P.-J. (2006). Histoire d'un dispositif francophone de formation ouverte et à distance [History of a Francophone open and distance learning system]. Distances et Savoirs, 4(1), 113-121. Retrieved from https://ds.revuesonline.com/gratuit/DS4 111 temoignageoillo.pdf

Peraya, D. (2008). La formation à distance dans les pays du Sud : Paroles et témoignages d'acteurs

[Distance learning in Southern countries: Words and testimonies of actors]. Distance et Savoirs, 6(4), 629-634. Retrieved from

https://ds.revuesonline.com/gratuit/DS6 4 11 lect crit Peraya.pdf

Tonye, E. (2008, May). La formation continue et à distance (FOCAD) en Afrique centrale : Étude de faisabilité contextualisée [Continuing and distance learning in Central Africa: Contextualised feasibility study]. Technical Report. Retrieved from https://www.researchgate.net/publication/301564594 La formation continue et a distan ce FOCAD en Afrique centrale etude de faisabilite contextualisee

Tonye, E. (2010). Modélisation d'un dispositif pour la formation ouverte et à distance dans les pays africains subsahariens [Modeling an open and distance learning system in Sub-Saharan African countries]. Frantice.net, 2, 72-85. Retrieved from http://www.frantice.net/docannexe/fichier/339/9_RIO2.pdf

Tonye, E. (2013). Le master en télécommunications en formation à distance (MASTEL) [Master's degree in telecommunications in distance education (MASTEL)]. In P.-J. Loiret (Ed.), $A$ detour through the future. Open and distance learning at the Agence Universitaire de la Francophonie 1992-2012 [A detour through the future. Open and distance learning at the Agence Universitaire de la Francophonie 1992-2012] (pp. 103-115). Paris: Archives Contemporaines.

Touré, M. (2014). La place de l'autonomie de l'apprenant dans la conception des formations ouvertes et à distance en Afrique de l'Ouest [The place of learner autonomy in the design of open and distance learning in West Africa]. International Journal of Technology in Higher Education, 11(3), 22-37. Retrieved from https://www.erudit.org/en/journals/ritpu/2014-v11-n3ritpu02140/1035701ar.pdf

\section{Athabasca University}

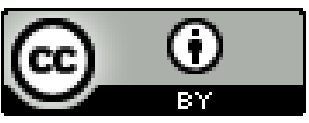

